\title{
Geology, Petrology and Amazing Geoforms of the Late Cenozoic Volcanic Province Erusheti Plateau (Lesser Caucasus) Georgia
}

\author{
B. Tutberidze and M. Akhalkatsishvili
}

\section{ABSTRACT}

These Erusheti Plateau is an integral part of the volcanic highland of Southern Georgia. It is located northern part of the Lesser Caucasus in the convergence zone of the Afro-Arabian and Eurasian lithosphere tectonic plates. The territory is almost totally covered with strong volcanic and volcano-sedimentary formations of Goderdzi suite with different lithologies and facies. The suite is formed in the Late Miocene - Early Pliocene Age, about from 11.8 \pm 4 to 13.6 \pm 3.1 Ma. Erusheti Plateau overall, are not characterized by many centers of eruption; Here we discuss eruption histories of the large polygenic volcanic massive Dokhuz-Puar and a monogenic volcano Datvistskaro are clearly seen among the volcanogenic structures of Erusheti Plateau. The eruption products of Dokhkuz-Puar volcano are dacitic-containing tuff-breccias and lava flows. The activity of Datvistskaro volcano was expressed only by the eruption of pyroclastic deposits containing andesite basalts. The main constituent minerals are: plagioclase and hornblende mega-crystals in dacites; augiteolivine and base plagioclase - in andesite basalts. With their geochemical properties, all the rocks of the rocks of a calc-alkali series. Dacites and andesite-basalts do not feed from a common magmatic source and consequently, are not the product of differentiation of the same magma. The work is the first to describe the natural amazing natural geoforms developed in pyroclastolites of Datvistskaro volcano: gigantic stone columns, mushroom-shaped stone caps and stone lances.Should be noted that no detailed mineralogical-petrological study of the rocks common in the study area has done to date. The main purpose of the given work is filling this gap.

Keywords: andesite basalt, Georgia, dacite, volcano.

Published Online: December 16, 2021

ISSN: $2684-446 \mathrm{X}$

DOI :10.24018/ejgeo.2021.2.6.223

\section{B. Tutberidze *}

Department of Geology, I. Javakhishili Tbilisi State University, Faculty of Exact and Natural Sciences, Tbilisi, Georgia.

(e-mail: bejan.tutberidze ${ }^{@}$ tsu.ge)

M. Akhalkatsishvili

Department of Geology, I. Javakhishili Tbilisi State University, Faculty of Exact and Natural Sciences, Tbilisi, Georgia.

(e-mail: mariam.akhalkatsishvili@tsu.ge)

\section{INTRODUCTION}

Erusheti Volcanic Plateau is located Northern Part of the Lesser Caucasus on Georgian-Turkish border, in the convergence zone of the Afro-Arabian and Eurasian lithosphere tectonic plates. A major part of the plateau is on the territory of Turkey and only a part of it with $60 \mathrm{~km}$ length and $20-25 \mathrm{~km}$ width is located on the territory of Georgia. The territory of the Plateau is dissected with numerous river valleys and is bordered by narrow $\mathrm{V}$-shaped gullies gorge [4], [6], [12] (Fig. 1).

The Erusheti Plateau includes by numerous peaks, the highest of which is the dome-like tectonic-volcanogenetic and erosional height Gumbati at $2964 \mathrm{M}$ asl.

The geological landscape of the study area is formed by strong lava and pyroclastic eruptions occurring in the Late Miocene-Early Pliocene Age, at the post-collision stage of the Afro-Arabian and Eurasian lithosphere plates e.g., [4], [10], [12]. The products of volcanic eruption of this period are known as "Goderdzi Suite" [7].

The suite is divided into two, pyroclastic (lower) and lava (upper) sub-suite with different lithologies and facies. The constituent rocks of the highland are basalts, andesite-basalts, andesites, dacites and rhyodacites, with dominant andesites and dacites. Goderdzi Suite shows a stratigraphic unconformity on the volcanogenic and volcanogenicsedimentary formations volcanic and volcanogenic sediments of the Middle Eocene and Oligocene Ages e.g., [10], [4], [12]. The K-Ar datings obtained for effusive rocks of the entire Goderdzi suite range from $11.8 \pm 4$ to $13.6 \pm 3.1 \mathrm{Ma}$ [4].

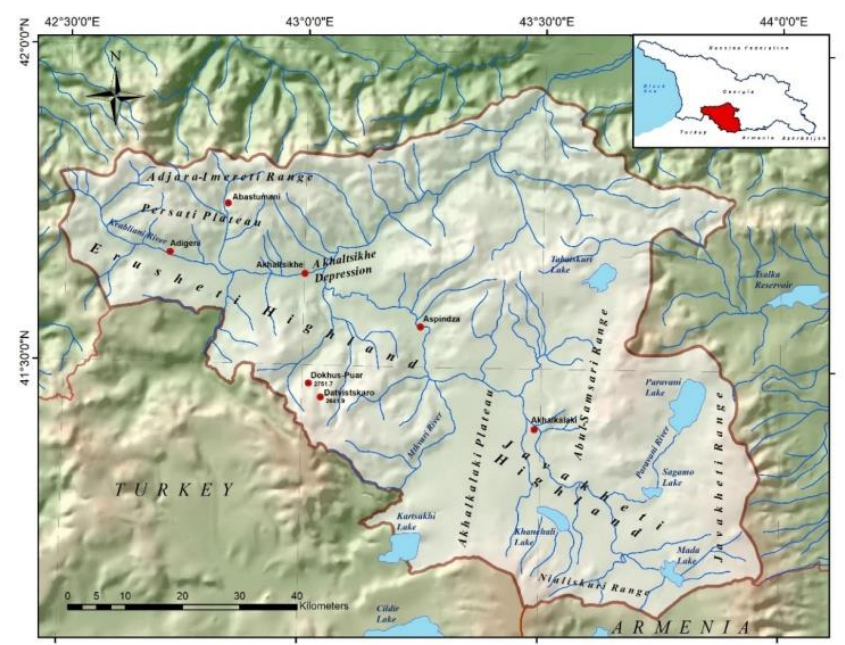

Fig. 1. The major morphostructural units in Southern Highlands of Georgia 


\section{GeOLOGY}

Geological structure and history of the development of volcanic processes on the territory of the Erusheti Plateau considered on the example of Dohkuz-Puar and Datvistskaro volcanoes.

\section{A. Volcano Dokhkuz-Puar}

Volcano Dokhkuz-Puar (2751 $\mathrm{m}$ asl) is the major morphological element of Erusheti Plateau. It is located in the central part of the plateau, between the valleys of rivers Rakisistskali and Saverdzasu. It is a powerful strong extinct polygenetic polygenic volcanic structure with steeply inclined northern and southern slopes. It is destructed due to the latter eruption and further strong erosive processes. The crater at the top of the cone not survived. Two episodes can be identified in the magmatic evolution process of the volcano: the first episode occurs with the eruption of dacitecontaining clastic non-cemented volcanic tuffa-breccia (the lower pyroclastic sub-suite, of Goderdzi Suite) and another episode ends with a dacite-containing lava flows eruption (upper lava sub-suite of Goderdzi Suite) (Fig. 2). There are no signs of stratigraphic unconformity seen between the subsuite. The lava flows from the eruption center flow in a radial direction and form a wide volcanic valley. The dacite sample taken from the top of Dokhkuz-Puar volcano was dated by the Late Miocene - Early Pliocene Age (11.8 4 to $13.6 \pm 3.1 \mathrm{Ma}$, by using K-Ar method [4]).

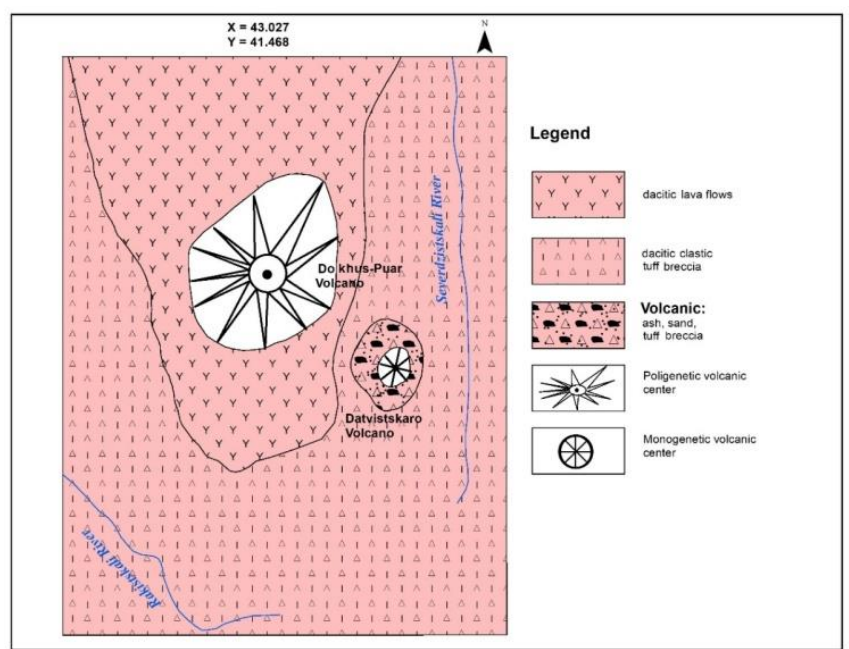

Fig. 2. Simplified geological maps (1:50 000) of Dokhuz-Puar showing Cenozoic volcanic fields (Modified from Jigauri and Petrosov 1989).

\section{B. Volcano Datvistskaro}

Datvistskaro Volcano (2641,9 m asl) is located 2-3 km south-east from the main volcanic center. It is a strong pyroclastic volcanic structure with wide steep eroded slopes, without the neck or crater. The action activity of Datvistskaro Volcano took place with the eruption of strong pyroclastic deposits in the Late Pliocene Age (analogs of the lower subsuite of Goderdzi Suite). There are three types of facies identified among the volcanogenic-sedimentary formations of Datvistskaro Volcano: volcanic sand (Fig. 3a), pelitic tuffs and breccias [4], [12]. The natural outcrops of these deposits are observed along the River Datvistskaro valley (the tributary of the River Saverdzasu).

Most of them are buried under the clastic volcanic tuffa- breccias of Dokhkuz-Puar volcano. The the thickness output of pyroclastolites is 30 to $100 \mathrm{~m}$. Due to the natural outcrops, a rhythmic alternation of ash tuffas and breccias are seen at $2620 \mathrm{~m}$ above sea level. They have almost sub-horizontal stratigraphy and small inclination angles (from $13^{\circ}$ to $15^{\circ}$ ) (Fig. 3b).

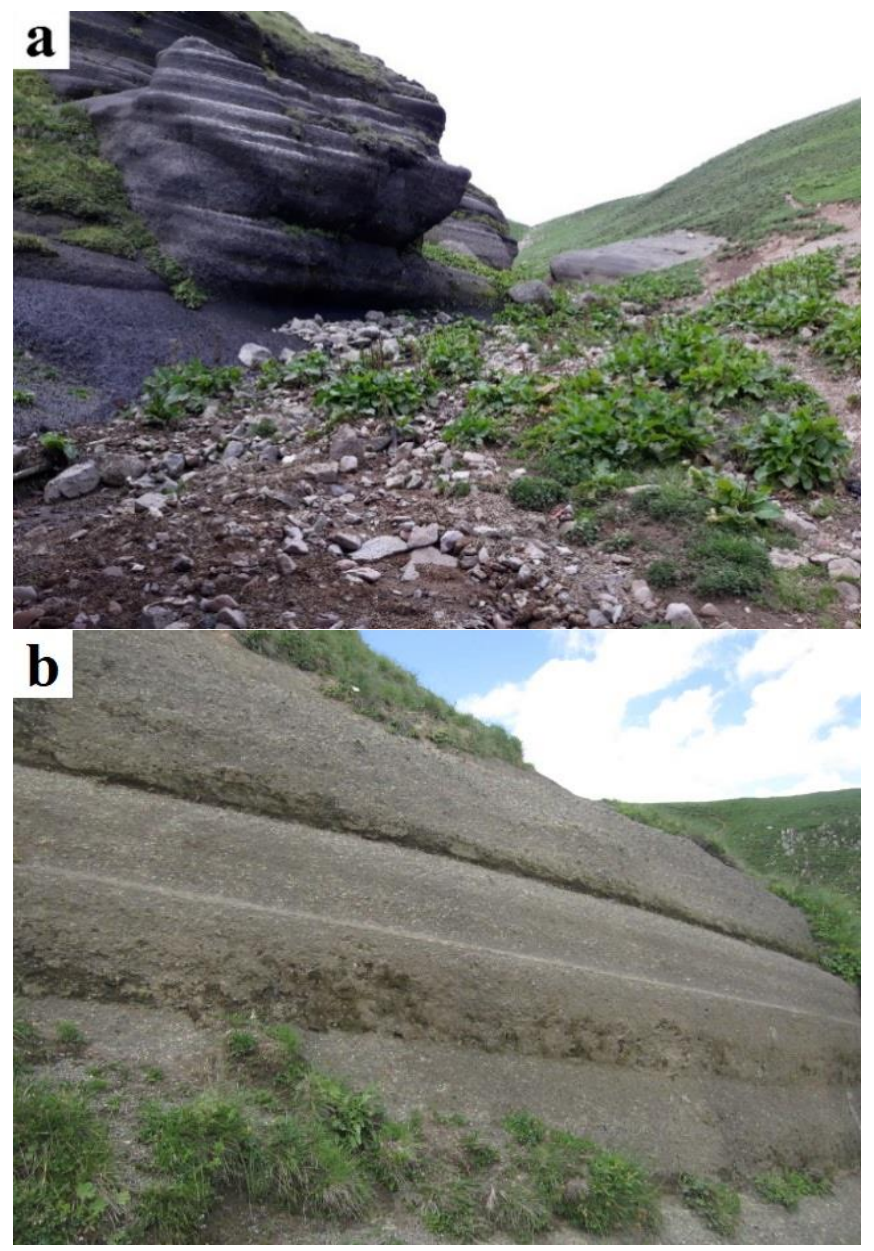

Fig. 3. The photo shows detail of outcrops black of volcanic sand with almost horizontal distribution beds (a), detail outcrops built of alternating layers of ash and tuff breccia, whit subhorizontal-laminated beds (b) (Author s photo).

Dark grey to black volcanic sands outcrop in the extreme lower part of a pyroclastic section.

They are slightly sorted, loose and crudely bedded. Their visible thickness is $10-15 \mathrm{~m}$ (the bedrock does not outcrop) (Fig. 4a).

The volcanic sand is rich multiple fragments of rocks ranging from to angular sub-angular shape (60-65\%). It is slightly porous. The sizes of sand particles vary from fine to coarse. Dominant are $0.2 \mathrm{~mm}-1 \mathrm{~cm}$ size grains (Fig. 4b). Fine-grained and loose volcanic ash (Fig.4c). Approximately 300-400 m north-west of the giv outcrops, at the sources of the Datvistskaro River, the lapillic breccias with often slagged brick-red rock fragments outcrop. The rock fragments in them are arranged chaotically and are cemented. The major portion of breccias is covered with fine brown volcanic ash. The sizes of rock fragments vary from several millimetres to several centimetres (Fig. 4d). 

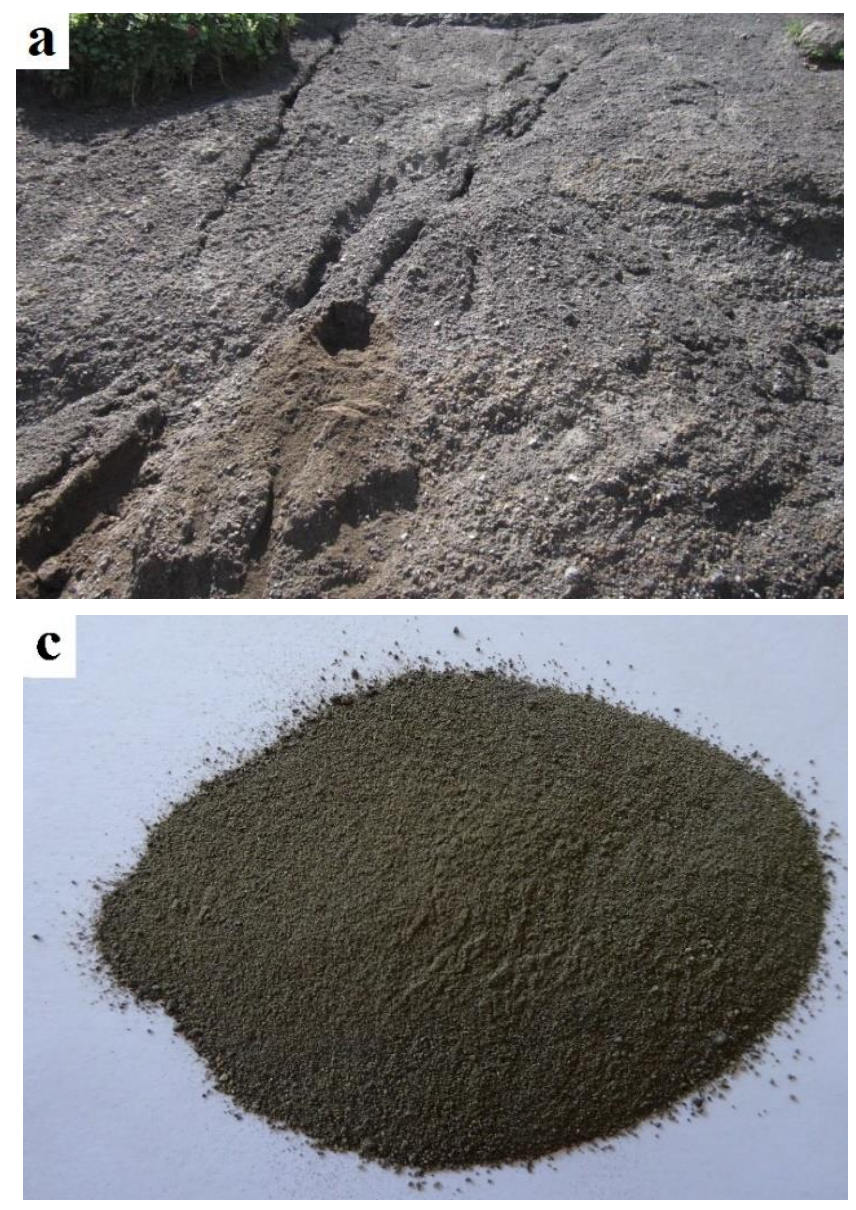

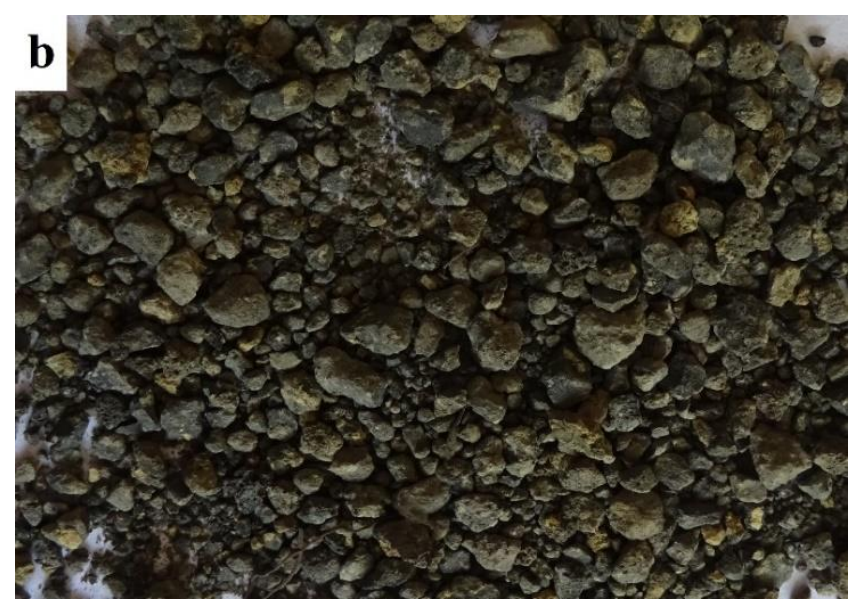

d

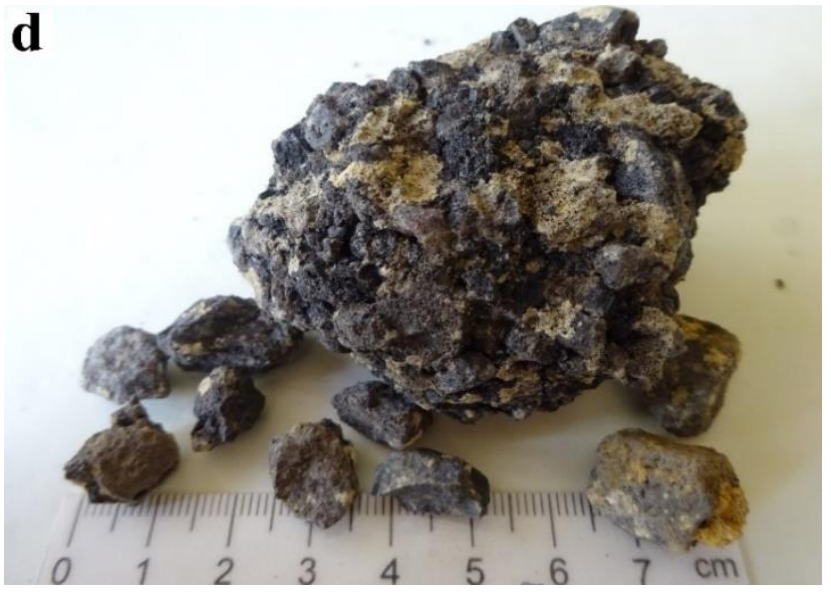

Fig. 4. The photo shows detail outcrop, of Datvistskaro pyroclastic deposits (a) (deposits much resemble lahar deposits); volcanic sand (b), volcanic ash (c); volcanic tuff breccia (d). (Author s photo).

\section{PETROGRAPHY}

\section{A. Petrography of Dokhkuz-Puar Volcano}

Dacites from Dokhuz-Puar volcano. These are macroscopically light grey to dark grey slightly porous rocks. Plagioclase and hornblende phenocrysts with dominant plagioclase are seen with a naked eye. Microscopically, the rock is characterized by porphyry, rarely glomeroporphyry structure. The structure of the groundmass changes from hyalopilitic to pilotaxitic. The phenocrysts are formed by plagioclases and amphibole. Clinopyroxene is rare or is totally absent. Other secondary or accessory minerals (iron oxides, chlorites, apatite) are found in small amounts.

Plagioclase is a widely spread widespread mineral phase in dacites of Dokhuz-Puar and makes 55-60\% of the total rock volume. There are 3 types of plagioclase: the first type is characterized by a distinct tabular shape; it is deformed and intensely resorbed in the inner core (Fig. 5a). Its content is calcium labradorite-bytownite (An62-An75). The second type is presented by individual phenocrysts with euhedral and subhedral crystals with a long-prismatic appearance. Their sizes vary from several millimeters to $1,5-2 \mathrm{~mm}$. The composition of plagioclase varies from the andesinelabradorite to andesine (An58 An46). The third type of plagioclase is presented by microlites. They are scattered in the glass-like groundmass of the rock. Plagioclase microlites usually has less anorthite molecules than phenocrysts (An35An47).

Amphibole is the main rock-forming non-ferrous mineral of the dacites of Dokhuz-Puar and makes 5-10 percent of the total rock volume. It mainly forms clusters of crystals as separate phenocrysts mostly of irregular shapes. It is rarely presented as column-like, long-prismatic crystals with a pseudohexagonal section (Fig. 5a). The rock shows the process of transition of common dark green hornblendes into black or grey basalt hornblende. The hornblende grains are partially to completely pseudomorphic with opaque minerals (presumably magnetite). Pyroxeneis not a typical component of Dokhuz-Puar dacites. It is extremely rare or absent. Therefore, with their mineral assemblage, the rocks of Dokhuz-Puar volcano belong to the plagioclase-hornblende dacites.

\section{B. Petrography of Datvistskaro Volcano}

The color of Datvistskaro volcanic sand changes from dark grey to black. It is poorly vesicular.Its texture is clastic, porphyritic (rarely glomeroporphyritic) with weakly expressed fluidal texture of holocrystalline groundmass. It consists of plagioclase, olivine, pyroxene, and secondary minerals. Plagioclase is present as short elongated prismatic aggregates (An58-An65).

It is rarely present jointly with pyroxene in glomerophyric overgrowths; sometimes it has simple twinning features. It is slightly altered due to clay minerals. Clinopyroxene (augite). Its color varies from greysh black to black. It is a very common mineral rock fragment (20-25\%). It mainly forms the crystals of a short prismatic shape and rarely forms hexagonal monocrystals with simple twinning. The size of clinopyroxene grains microlite groundmass is within the range of $0.02-0.05 \mathrm{~mm}$ and within the range of $1,5-2,5 \mathrm{~mm}$ in 
phenocrysts. The secondary minerals of alteration are chlorites and iron oxides. Olivine is a common mineral in lithic fragments (10-12\%). They may occur both, as phenocrysts and microlites in a glass-like groundmass (Fig. $5 b)$. The shape of phenocrysts changes from sub-idiomorphic to anhedral. The grain sizes vary from $2-3 \mathrm{~mm}$ to $0.02-0.04$ $\mathrm{mm}$ (microlite). The composition of olivine varies within the range of Fo78 and Fo83. Sound olivine crystals are rare in the nature. Rather, the crystals are transformed into secondary minerals either totally, or partially. Large olivine crystals are mainly altered in the rims and with orange-brown, reddish brown, and sometimes, yellowish green iddingsite and bowlingite along microfissures. Sometimes, there are bowlignite and iddingsite pseudomorphs to olivine.

Volcanic tuff. The color of volcanic tuff ashes varies from light grey to black; its texture is vesicular; its structure is porphyritic, with the groundmass of a pilotaxitic to hyalopilitic structure. It consists of the fragments of scoria, minerals, and volcanic glass (Fig. 5c). The scoria fragments are highly vesicular (50-55\%).

The vesicles are mostly round and only rarely elliptical or of an irregular shape. The vesicles are often separated from one another, but sometimes they coalesce and form dumbbell shapes [9] (Fig. 5c). The scoria fragments are made up of plagioclase, pyroxene, olivine, opaque minerals (possibly magnetite) and volcanic glass.

Plagioclase is the most common mineral. It almost entirely occurs as small elongated crystals oriented chaotically in the groundmass. Phenocrysts are rare. Their composition varies from An3 to An67. Olivine occurs in small amounts (.3-5\%). It is a part of both, the scoria fragments, and individual isolated phenocrysts (Fig. 5d).

The shape of phenocrysts varies from subhedral to anhedral, and they are sized 2,5 $\mathrm{mm}$. Olivine is relatively sounder. The secondary minerals (bowlingite, iddingsite) are sometimes observed in the peripheral areas of a crystal and along micro-fissures. Pyroxene (augite) occurs as microlites only. Its orientation is chaotic together with plagioclases and olivine in the glass groundmass.

Macroscopically, tuff breccia is a dark grey, rusty, or rustbrown rock with the inclusions of fragments of intensely slagged brick-red rock of an irregular shape and various sizes (Fig. 5d). Its structure comes with clastic, oligophyric, pylotaxitic or slightly fluidal groundmass. The main rockforming minerals are plagioclase, olivine, clinopyroxene and magnetite. Plagioklase Plagioklace is the dominant phase in lithic fragments. It occurs as small needle-shaped crystals with a slightly subparallel orientation in the fine groundmass. The rock fragments contain only few phenocrysts of olivine (Fo78). They are deformed and often with microfissures filled with secondary minerals, such as iddingsite, bowlingite, chlorites or iron oxides (Fig. 5d). Plagioclase is the most common mineral in a groundmass. Opaque minerals (possibly magnetite or hematite) and olivine also occur in little amounts.
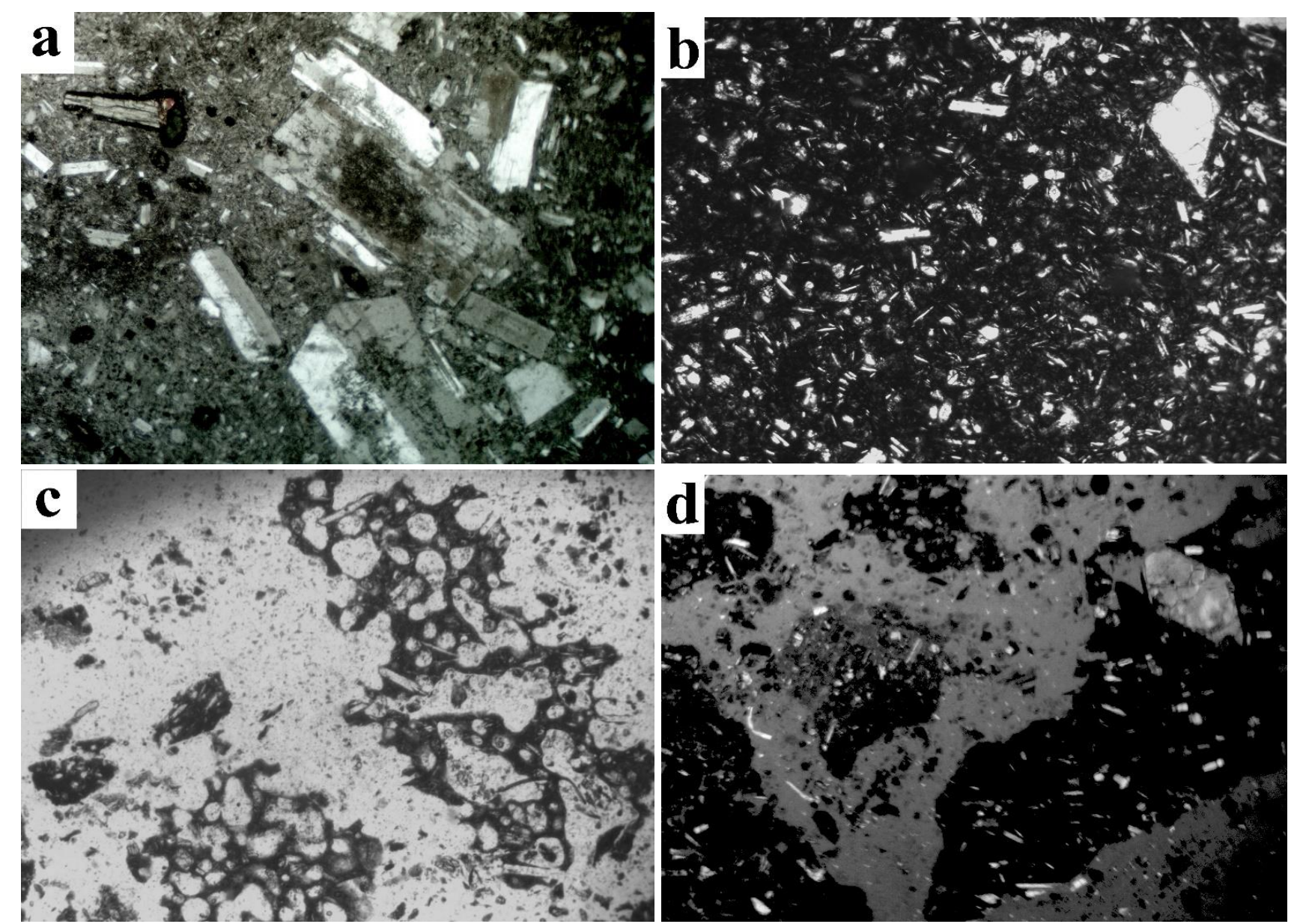

Fig. 5. Optical microscopy images of thin section of the rocks of Dokhuz-Puar volcanic area: (a) The dacite sample contains phenocrysts of plagioclase and amphibole, the view is in crossed polar s ; (b) volcanic sand contains small amount of individual phenocryst olivine, plagioclase and pyroxene microlites (the view is in crossed polar s); (c) Volcanic ash contain fragments of scoria, olivine phenocryst and glass. Mineral compositions of the scoria are plagioclase, olivine and pyroxene (the view is in plane-polarized light); (d) the tuff-breccia contains abundant angular lithic fragments; mineral compositions of the lithic fragments are predominantly phenocrysts of olivine, plagioclase and pyroxene microlites (the view is in crossed polar s). 


\section{PETROCHEMISRTY}

The composition of the main rock-forming oxides (in wt $\%)$ of Dokhuz-Puar volcanic area is given in Table I.

\section{A. Petrochemistry of Datvistskaro Volcano}

The volcanic breccias and lava currents flows from Dokhuz-Puar volcano have similar chemical compositions. However, the content of potassium is higher (3.20 wt.\%) in tuff-breccias as compared to lava currents (1.86 wt.\%). The rocks are classified as dacites (see Table I, chemical analysis 11-12).

The chemical analysis data for Datvistskaro volcano are similar to those given above, in particular: $\mathrm{SiO}_{2}$ oxides vary within the range of 53.7-56.48 wt.\%; $\mathrm{TiO}_{2}$ varies within 0.0.80-0.86 wt.\%, $\mathrm{Al}_{2} \mathrm{O}_{3}$ varies within 16.30-17.10 wt.\%; $\mathrm{Fe}_{2} \mathrm{O}_{3}$ varies within 2.35-3.20 wt.\%; FeO varies 2.803.80 wt. $\%$; $\mathrm{MgO}$ varies within 5.80- 6.30 wt. $\%$; $\mathrm{CaO}$ varies within 6.40-6.80 wt. $\%$; $\mathrm{Na}_{2} \mathrm{O}$ varies within 3.50-3.73 wt.\%; $\mathrm{K}_{2} \mathrm{O}$ varies within $1.48-1.73$ wt.\%; $\mathrm{P}_{2} \mathrm{O}_{5}$ varies within 0.45 $0.80 \mathrm{wt} . \%$; and LOI varies within $1.50-2.20 \mathrm{wt} . \%$. With these data, the pyroclastolites with different facies from Datvistskaro volcano correspond to andesite-basalts (see Table I, chemical analysis 1-10).

Various geochemical discrimination graphs were used to provide the chemical classification of the rocks from DokhuzPuar volcanic province.

\section{B. Petrochemistry of Dokhuz-Puar Volcano}

The figurative point showing the composition of lavas of Dokhuz-Puar volcano is found in the field of rocks of calcalcaline and sub-alkaline series in $\mathrm{K}_{2} \mathrm{O}+\mathrm{Na}_{2} \mathrm{O}-\mathrm{SiO}_{2}$ graph [5]. The figurative point of tuff breccias is found on the separating line between the rocks with calc-alcaline and sub-alkaline composition (Fig. 6). All figurative points showing the compositions of pyroclastolites from Datvistskaro volcano are found in the field of rocks of calc-alcaline series (Fig. 6).

All figurative points in discrimination AFM $\left(\mathrm{Na}_{2} \mathrm{O}+\mathrm{K}_{2} \mathrm{O}\right.$, $\mathrm{FeO}, \mathrm{MgO}$ ) ternary graph showing the composition of rocks of Dokhuz-Puar volcanic province are found in the field of rocks of calc-alcaline series (Fig. 7).

The figurative point in the binary $\mathrm{K}_{2} \mathrm{O}$ vs $\mathrm{SiO}_{2}$ graph [2] showing the composition of the rocks in the study region, suggest that except Dokhuz-Puar tuff-breccias, the rocks are classified as rocks from low-potassium calc-alkaline series. The figurative point of tuff-breccias is in the field of rocks from high-potassium calc-alkaline series (Fig. 8).

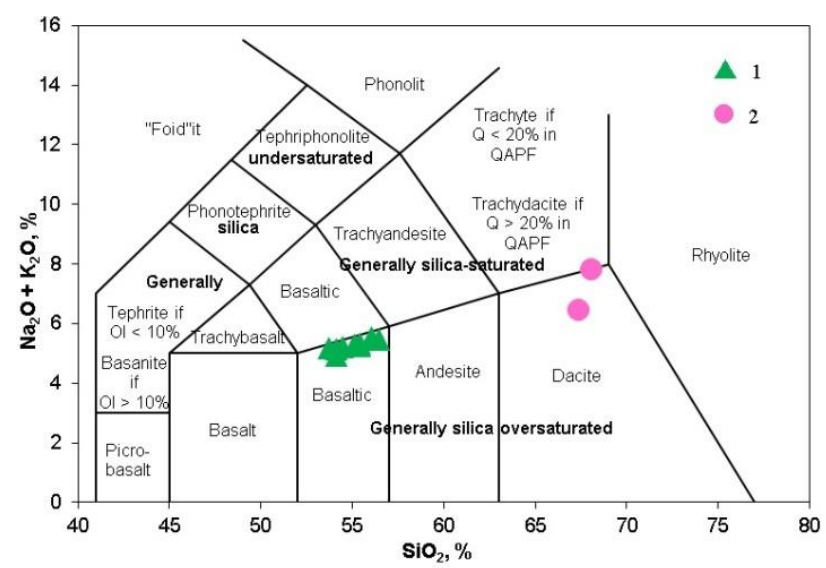

Fig. 6. $\mathrm{K}_{2} \mathrm{O}+\mathrm{Na}_{2} \mathrm{O}$ vs $\mathrm{SiO}_{2}$ diagram from [5] of volcanic rocks from the Dokhuz-Puar volcanic field. (Symbols as for Table I).

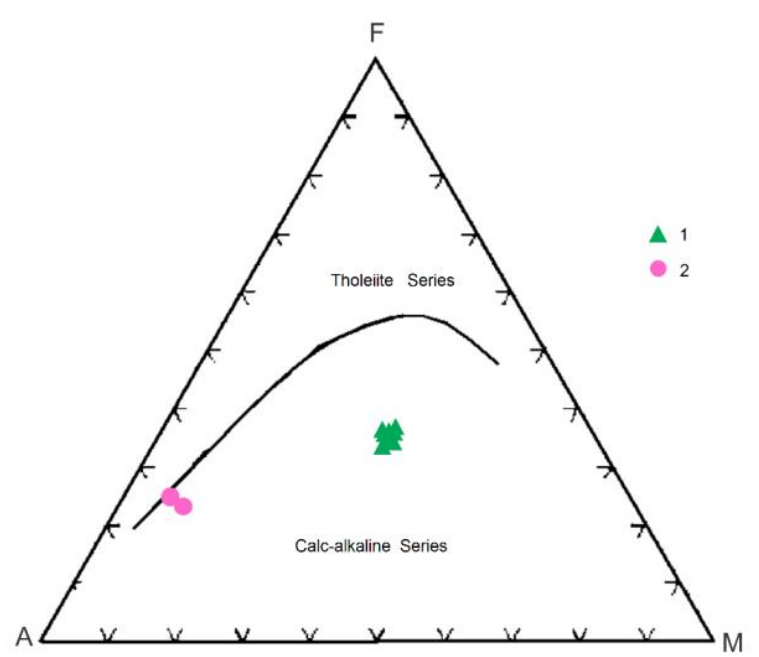

Fig. 7. AFM ternary diagram from [3] of volcanic rocks from the DokhuzPuar volcanic field (Symbols as for Table I).

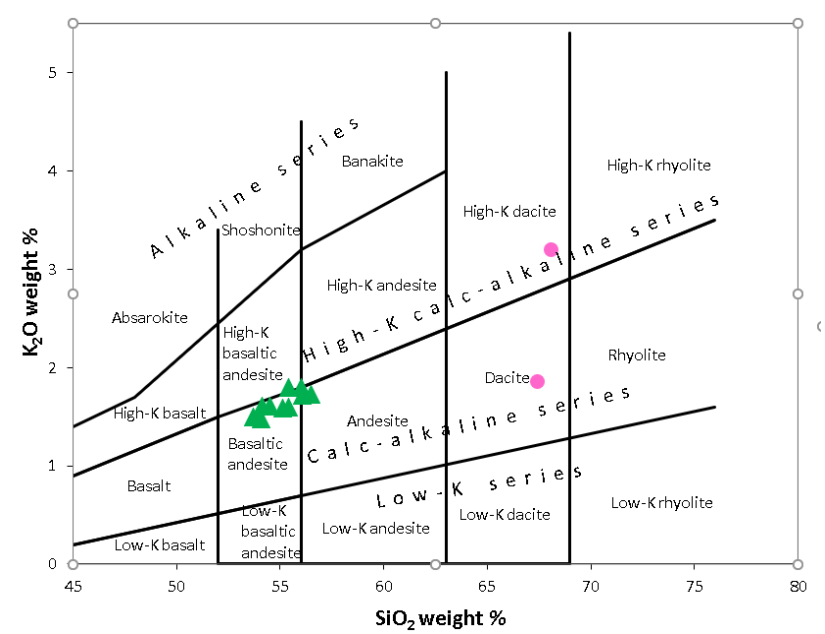

Fig. 8. $\mathrm{K}_{2} \mathrm{O}-\mathrm{SiO}_{2}$ discrimination diagram from [2] of volcanic rocks from the Dokhuz-Puar volcanic field. The samples in fact astride the boundary line dividing calc-alkaline and high-K calc-alkaline fields (symbols as for Table I).

\section{AMAZING GEOFORMS}

\section{A. Amazing Geoforms of Volcanic Relief of Datvistskaro}

Dokhuz-Puar volcanic province attracts attention with its naturally amazing geoforms. of its natural cliffy formations. These formations were found on the territory of Datvistskaro volcano by me during my work on Erusheti Plateau [12]. They form a very beautiful scenery of the nature and are presented by columns (6-7 m) (Fig. 9 a, b), mushroom-like (2-2.5 m) (Fig. 9c) and lance-shaped (1-1.5 m) (Fig. 9d).

\section{B. The Origin of Amazing Geoforms}

They were formed under the joint action of aggressive erosive and weathering agents (river action, seasonal temperature oscillations, wind, glaciers, and downpours) on pyroclastic deposits. The selective nature of erosive and weathering processes is clear on the example of the said formations as a result of different physical properties (hardness, brittleness, grain size, density, permeability and porosity) of pyroclastic rocks of various facies of Datvistskaro volcano.

There are many researchers suggesting that the formation of such landforms is the result of selective erosion and 
weathering processes of pyroclastic deposits [1], [8], [11], [13]. It should be noted that the action of weathering agents on the territory of Datvistskaro volcano is still active to date and may cause the formation of new forms. It should also be noted that these processes have a negative impact on the already existing forms in the area, what, on its turn, is a serious threat for the stability of the said forms.

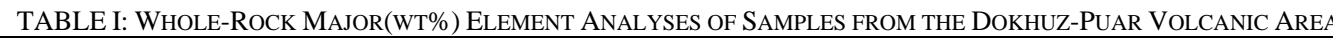

\begin{tabular}{|c|c|c|c|c|c|c|c|c|c|c|c|c|}
\hline $\begin{array}{c}\text { Sample } \\
\mathrm{N}\end{array}$ & $\begin{array}{c}1 \\
(2302)\end{array}$ & $\begin{array}{c}2 \\
(2303)\end{array}$ & $\begin{array}{c}3 \\
(2305)\end{array}$ & $\begin{array}{c}4 \\
(2306)\end{array}$ & $\begin{array}{c}5 \\
(2307)\end{array}$ & $\begin{array}{c}6 \\
(2309)\end{array}$ & $\begin{array}{c}7 \\
(2310)\end{array}$ & $\begin{array}{c}8 \\
(2311)\end{array}$ & $\begin{array}{c}9 \\
(2312)\end{array}$ & $\begin{array}{c}10 \\
(2313)\end{array}$ & $\begin{array}{c}11 \\
(2308)\end{array}$ & $\begin{array}{c}12 \\
(2314)\end{array}$ \\
\hline $\begin{array}{c}\text { Major } \\
\text { Elements } \\
\text { (wt } \%)\end{array}$ & $\boldsymbol{\Delta}$ & $\boldsymbol{\Delta}$ & $\boldsymbol{\Delta}$ & $\Delta$ & $\boldsymbol{\Delta}$ & $\boldsymbol{\Delta}$ & $\boldsymbol{\Delta}$ & $\boldsymbol{\Delta}$ & $\boldsymbol{\Delta}$ & $\boldsymbol{\Delta}$ & 0 & $\bullet$ \\
\hline $\mathrm{SiO}_{2}$ & 54.5 & 54.1 & 56.06 & 56.48 & 55.4 & 55.1 & 56.04 & 54.14 & 53.7 & 55.42 & 68.1 & 67.4 \\
\hline $\mathrm{TiO}_{2}$ & 0.8 & 0.86 & 0.8 & 0.8 & 0.82 & 0.8 & 0.8 & 0.85 & 0.85 & 0.8 & 0.45 & 0.35 \\
\hline $\mathrm{Al}_{2} \mathrm{O}_{3}$ & 17.1 & 16.8 & 16.8 & 16.5 & 16.7 & 16.4 & 16.3 & 17.3 & 17.3 & 17.1 & 16.2 & 17.58 \\
\hline $\mathrm{Fe}_{2} \mathrm{O}_{3}$ & 3.1 & 2.96 & 2.5 & 2.52 & 3.2 & 2.64 & 2.5 & 2.8 & 2.75 & 2.35 & 1.98 & 1.68 \\
\hline $\mathrm{FeO}$ & 3.3 & 3.4 & 3.3 & 3.8 & 2.8 & 3.20 & 3.3 & 3.53 & 3.53 & 3.6 & 0.8 & 0.61 \\
\hline $\mathrm{MnO}$ & 0.08 & 0.08 & 0.05 & 0.08 & 0.08 & 0.08 & 0.06 & 0.08 & 0.08 & 0.08 & 0.03 & 0.02 \\
\hline $\mathrm{MgO}$ & 6.1 & 6.25 & 6.3 & 6.2 & 5.8 & 6.3 & 6.12 & 6.3 & 6.6 & 6.3 & 1.01 & 1.02 \\
\hline $\mathrm{CaO}$ & 6.7 & 6.4 & 6.6 & 6.7 & 6.8 & 6.5 & 6.7 & 6.8 & 6.6 & 6.7 & 3.24 & 3.8 \\
\hline $\mathrm{Na}_{2} \mathrm{O}$ & 3.59 & 3.46 & 3.73 & 3.73 & 3.5 & 3.69 & 3.73 & 3.51 & 3.69 & 3.65 & 4.58 & 4.58 \\
\hline $\mathrm{K}_{2} \mathrm{O}$ & 1.61 & 1.48 & 1.72 & 1.73 & 1.8 & 1.59 & 1.8 & 1.61 & 1.5 & 1.6 & 3.20 & 1.86 \\
\hline $\mathrm{P}_{2} \mathrm{O}_{5}$ & 0.44 & 0.8 & 0.2 & 0.32 & 0.5 & 1.55 & 0.32 & 0.38 & 0.4 & 0.45 & 0.40 & 0.49 \\
\hline LOI & 2.5 & 3.1 & 2.1 & 1.5 & 2.5 & 2.02 & 2.3 & 2.6 & 2.7 & 2.05 & 0.30 & 0.80 \\
\hline $\mathrm{H}_{2} \mathrm{O}^{-}$ & 0.68 & 0.8 & 0.28 & 0.12 & 0.6 & 0.6 & 0.5 & 0.6 & 0.8 & 0.4 & 0.20 & 0.30 \\
\hline Total & 100.5 & 100.49 & 100.44 & 100.48 & 100.5 & 100.47 & 100.47 & 100.5 & 100.5 & 100.5 & 100.49 & 100.49 \\
\hline
\end{tabular}

1-2 volcanic sand; 3-black ash, 4-5 black sand from table-like form (Fig. 10c,); 6-black sand from eolian -copie stone (Fig. 10d), 7-volcanic ash (Fig. 5c); 89-tuff breccia of the rock pillar (Fig. 10 a, b), black send (Fig. 4 a);11- dacitic clastic tuff breccia, 12-dacitic lava flows.
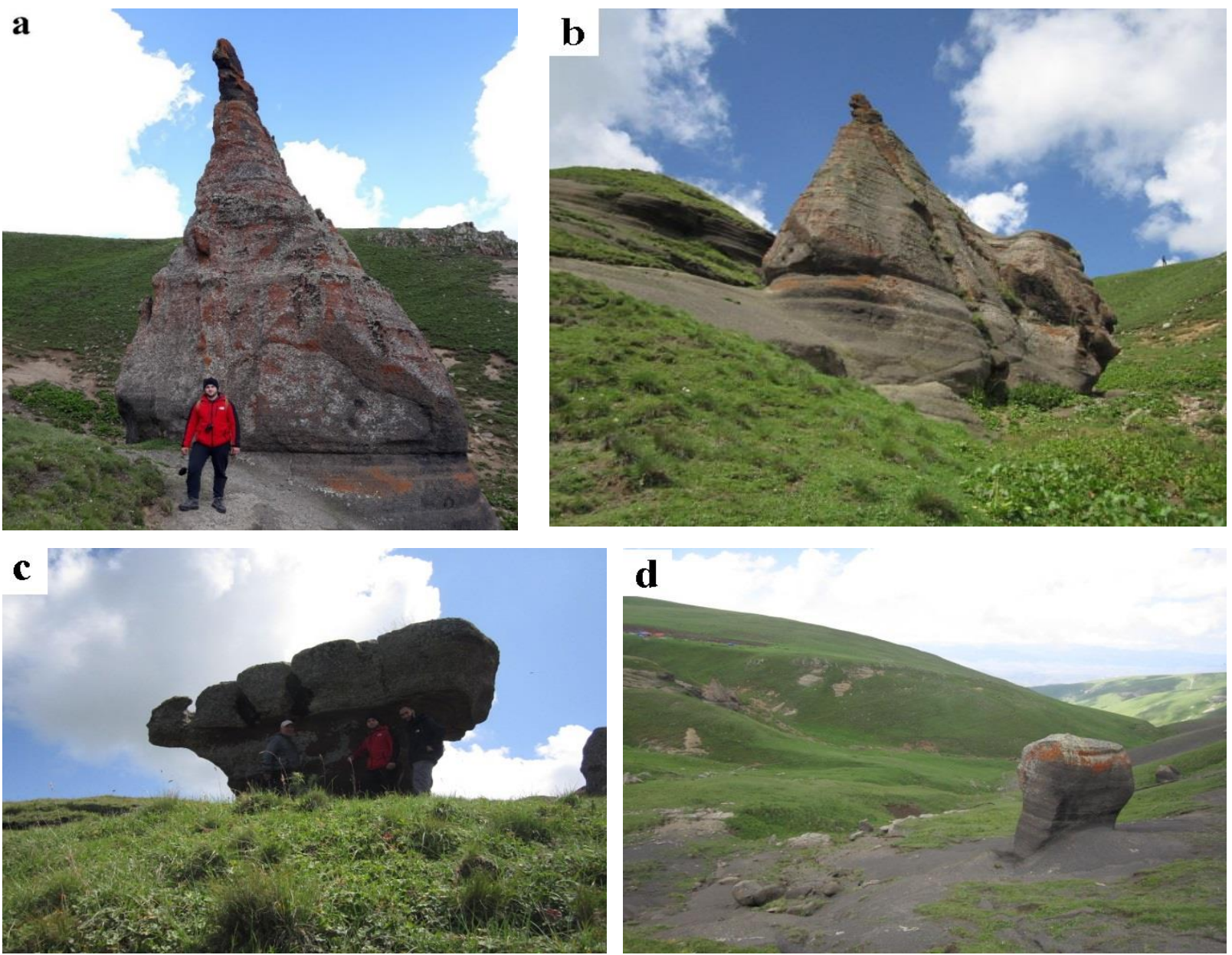

Fig. 9. Photos of bizarre shapes in pyroclastic sediments of the Datvistskaro volcano: stone pillar (a, b forms are the same), mushroom-like (c) and, copies-like (d) forms (Author s photo). 


\section{CONCLUSIONS}

1. The volcanic activity in the Erusheti Plateau and in the volcanic region of South Georgia is the result of the evolution of the history of post-collision stage of the Afro-Arabian and Eurasian continental lithospheric plates starting in the UpperMiocene and continuing through the Lower Pliocene (i.e., from $11,8 \pm 4$ to $13.6 \pm 3 \mathrm{Ma}$ ). The age of the volcanic formations was determined by using the K-Ar radiometric method.

2. The volcanic landscape of Dokhuz-Puar Province was formed with lava-pyroclastic eruption products of polygenic Dokhuz-Puar Volcano and monogenic Datvistskaro Volcano. The history of evolution of Dokhuz-Puar Volcano clearly shows two episodes of activity: the first episode took place with the eruption of tuff-breccias with dacitic content, while the second episode occurred and ended with the eruption of strong homogeneous dacite lava flows. No stratigraphic nonconformity was observed between the eruption products of the episodes. The eruption products of Datvistskaro Volcano are presented by different-facies pyroclastic deposits: volcanic ash, volcanic sand, and volcanic breccias.

3. The dacites from Dokhuz-Puar Volcano are almost entirely built with phenocrysts of idiomorphic and subidiomorphic plagioclases and amphiboles with a minor content of pyroxenes. The secondary minerals are magnetite and rarely chlorides. The glass groundmass contains the same mineral assemblage as the phenocrysts do. The pyroclastic deposits of Datvistskaro Volcano, despite their different rock facies, have a similar composition: plagioclase, olivine, and augite. Anhedral and euhedral forms of phenocrystals are quite common. Secondary minerals are: bowlingite, iddingsite, iron oxides, magnetite, and chlorite. With their mineralogical composition, they are limited to andesite-basalt rocks.

4. As the results of petrographic-chemical analysis suggest, the rocks of the calc-alkaline series with moderate $K$ (dacite lava flows) and high $\mathrm{K}$ (dacite lava breccias) of Dokhuz-Puar volcanic rocks are noteworthy. All pyroclastic deposits of Datvistskaro Volcano are the rocks moderate K-calc-alkaline series. Their petrographical, mineralogical and petrochemical similarity allows assuming that they had a common magmatic hearth feeding them. At this point, we must note that Dokhuz-Puar and Datvistskaro volcanites cannot be viewed as the products of differentiation of a common magma differentiation.

5. The natural amazing forms developed in the pyroclastic sediments of Datvistskaro Volcano were described by us for the first time. The said forms are an excellent example of the product of selective weathering and erosion processes: the reason for such processes is the heterogeneity of granulometric composition, hardness, varying degrees of cementation, porosity, and permeability of pyroclastic deposits. The study area has all kinds of weathering agents: prevailing wind, seasonal and regional climate changes, snow and glacier melting, river and heavy atmospheric precipitations. The amazing alpine volcanic landscape of Dohkuz-Puir Province is a new prospect for the country's touristic potential.

6. Dohkuz-Puir Province is distinguished by large amounts of construction materials. The pyroclastolites can be successfully used as an additive to Portland cement, as light concrete aggregate used for the maintenance and construction works of the road mains and highways.

\section{REFERENCES}

[1] D.Calcaterra, D. Coppin, S. De Vita, M.A. Di Vito, G.Orsi, B. Palma, and M. Parise. Slope process in weathered volcanoclastic deposits within the city of Naples. The Camaldoli Hill case. Journal Geomorphology, 2007;87(3):132-157.

[2] A. Ewart. The mineralogy and petrology of Tertiary-Recent orogenic volcanic rocks: with special reference to the andesitic-basaltic compositional range. In: Andesites orogenic andesites and related rocks. Thope, (editors), John Wiley and Sons, Chichester p. 25-95. 1982.

[3] T.N. Irvine,. and W.R.A Baragar. A Guide to the Chemical Classification of the Common Volcanic Rocks. Canadian Journal of Earth Science, 8, 523-548, 1971

[4] D. G. Jigauri, and N.G. Petrosov. Composition and correlation of lithologic and stratigraphic schemes of continental effusive formations of southern Georgia. Report cartographic party on the results of thematic work carried out in 1981-1985, report text, 195 p. (in Russian) 1989.

[5] M.J. Le Bas, R.W. Le Maitre, A Streckeisen and B. Zanettin. A Chemical classification of volcanic rocks based on the total alkali-silica diagram. Journal of Petrology, 1986;27(3):745-750.

[6] L. Maruashvili, Geomorphology of Georgia, Tbilisi, 309 p. (in russian). 1971.

[7] B.F. Meffert. Geological outline of the Upper Kura basin, material for the general scheme of the use of water resources of the Kura-Araks basin, vol. 5, Tbilisi 1933 .

[8] M. A Sarikaya, A. Ciner, and M. Zreda. Fairy chimney erosion rates on Cappadocia ignimbrites, Turkey: Insights from cosmogenic nuclides. Journal Geomorphology, 2015; 234:182-191.

[9] S. Sensarma, H. Singh, S. R. Rana, and D Paul. Nature and composition of interbedded marine basaltic pumice in the $\sim 52-50$ Ma Vastan lignite sequence, western India: Implication for Early Eocene MORB volcanism offshore Arabian Sea. Journal of Earth System Sciense, 2017;126(17):2-19. https://doi.org/10.1007/s12040-017-0806-2.

[10] N. Skhirtladze. Post-Paleogenic Effusive Volcanism of Georgia. Tbilisi, 333 p. (in Russian) 1958.

[11] T. Topal, and V. Doyuran. Engineering geological properties and durability assessment of the Cappadocia Tuff. Engineering Geology, 1997; 47:175-187.

[12] B. Tutberidze. Geology and Petrology of the Late Orogenic Magmatism of the Central Part of the Caucasian Segment. Tbilisi, 339 p. (in russian). 2004

[13] H.M. Yilmaz, M. Yakar, O. Mutluoglu, M.M Kavurmaci, and K. Yurt. Monitoring of soil erosion in Cappadocia region (Selime-AksarayTurkey). Journal Environ Earth sciences, 2012;66 (1):75-81. https://doi.org/10.1007/s12665-011-1208-4.

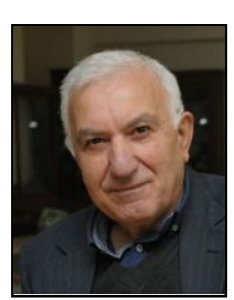

\section{Bezhan Tutberidze}

Proffessor, Doctor of Geological Science; Head of the department of Geology, of the faculty of Exact and Natural Sciences at I. Javakhishvili Tbilisi State University; Head of the Chair of mineralogy, petrography and useful minerals at I. Javakhishvil Tbilisi State University; 2007-2011 Director Institute of Geology of the faculty of Exact and Natural Sciences at I. Javakhishvili Tbilisi State University; 2003-2005 Dean of the Faculty of Geology at I. Javakhishvili Tbilisi State University; Works are entirely devoted to the complex research of young (Cenozoic) volcanoes and its products in Georgia and the adjacent territories.

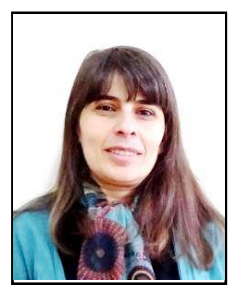

Mariam Akhalkatsishvili

Candidate of Science in Geology and Mineralogy; assistant professor at Ivane Javakhishvili Tbilisi State University, Faculty of Exact and Natural Sciences. 2000-2007 - Engineer-geologist, 2007-2008 - Head of the Petrochemical laboratory. Research interests: Mineralogy, Petrology, Volcanology. Total number of published scientific works - up to 25 . 